\title{
Study on Health Status of the Workers in the Transport Sector
}

\section{Edirisinghe B L}

MD scholar in Swasthavritta, Post graduate Institute of Indigenous Medicine, Sri Lanka

\section{Matarage N P}

Community Medical Officer - In charge (Maharaga AGA Division)

\section{Kulathunga W M S S K}

Senior lecturer, Grade 1, Institute of Indigenous Medicine, Sri Lanka

DOI - http://doi.org/10.37502/IJSMR.2021.4703

\begin{abstract}
A Bus depot is a transport system's operating base. It provides parking accommodation, servicing and maintenance facilities for buses and administrative function and facilities for the staff. Operators may have their own facilities in very basic level. The principal operational tasks that carried by the depot are allocating buses and crews to each duty, Dispatching buses according to schedule and processing cash paid in by conductors or drivers. The objective of the study was to define health status of the staff of the Bus depot at Maharagama. This was descriptive cross- sectional study carried out in depot staff at Maharagama. All study samples has done the screening tests such as BP, Random Blood Sugar, Body mass index, urine trace identification of Non communicable diseases and Astavidapriksha. Sample size for the study was 54. Response rate was $100 \%$. Results were calculate by using SPSS 16 version presenting descriptive statistics such as mean, standard deviation and frequencies. The ages of the study participants ranged from 29 to 56 years, with mean age of $42.36+6.76$ years. $97.5 \%$ of them were single, $2.5 \%$ of them were female and they were working as office staff. Majority of the respondents were bus drivers representing $58.2 \%$ ( 71) of the sample. Nearly one fourth of the respondents were healthy not any victim of Non communicable diseases presenting 30\% (36). There was a significant differences among the nutritional status and Non- communicable diseases of the respondents' following the $\mathrm{X} 2(1, \mathrm{~N}=120)=0.422, \mathrm{p}=0.031$. It shows that there was a relationship between nutritional status and Non- communicable diseases of the workers at the Bus depot which is $\mathrm{p}$ value less than 0.05 .
\end{abstract}

Key words: Drivers, Health status, Non communicable diseases.

\section{Introduction}

A Bus depot is a transport system's operating base. It provides parking accommodation, servicing and maintenance facilities for buses and administrative function and facilities for 
the staff. Operators may have their own facilities in very basic level. The principal operational tasks that carried by the depot are allocating buses and crews to each duty, Dispatching buses according to schedule and processing cash paid in by conductors or drivers. In a depot very hardworking duties are doing by bus drivers, conductors and mechanic who are repairing buses. Due to the busiest daily routine they neglect to pay attention on their health. The health condition of public transport drivers is one of the factors playing a role in assuring safety of passengers (Zuzanna Szubert at el, 2005). According to WHO, Nutritional status of an individual is the condition of the body as a result of the intake, absorption and use of nutrition? Study has shown that the Nutrition is a fundamental pillar of human life, health, and development across the entire lifespan (WHO, FAO, 1992). WHO has shown that from the earliest stages of fetal development, at birth, through infancy, childhood, adolescence, and into adulthood and old age, proper food and good nutrition are essential for survival, physical growth, mental development, performance of the productivity and wellbeing (WHO, 2000). Studies from developed countries reported obesity epidemic, which is one of the major reasons for non-communicable diseases (NCD. Alliance report 2012-2013). Over nutrition also has become a serious public health problem in the world. From 1975 t0 2016, the world wide prevalence of obesity has nearly tripled. According to WHO, in 2016, more than one third of adults were overweight (39\%) and were obese 13\%. Some older studies conducted to assess the nutritional status among male adult workers in developing countries showed that underweight was prevalent and low overweight and obesity were present (M. D. Hossain at el, 2015). Researches have shown that if there is increase in occupational stress it affects nutritional status and it will create health problems (Ronnenbeg, A.G at el, 2000). Many studies have indicated that interrelation between nutritional status and occupational stress (Medhi, G.K. at el, 2006) Studies have proved that bus drivers were suffered from cardiovascular diseases including hypertension, gastrointestinal diseases including peptic ulcers and muscular skeletal problems including back and neck pain. The assessment of pathologies occurring in this occupational group is essential from the prevention point of view.

\section{Objectives}

The aim of the study was to identify the health status of the staff of the Bus depot at Maharagama.

\section{Methodology}

This was descriptive cross- sectional study carried out in depot staff at Maharagama. All study samples has done the screening tests such as BP, Random Blood Sugar, Body mass index, urine trace identification of Non communicable diseases and Astavidapriksha. Sample size for the study was 54 . Response rate was $100 \%$. Results were calculate by using SPSS 16 version presenting descriptive statistics such as mean, standard deviation and frequencies.

Done screening test in following areas

- Astavida pariksha

- Blood pressure 
- Pulse rate

- Body Mass index

- Random Blood Sugar

- Urine trace

- Identification of Non communicable diseases

\section{Results}

A total number of the participants for the screening program were 120 . The ages of the study participants ranged from 29 to 56 years, with mean age of $42.36 \pm 6.76$ years. $97.5 \%$ of them were single, $2.5 \%$ of them were female and they were working as office staff. Majority of the respondents were bus drivers representing $58.2 \%$ ( 71) of the sample. 93.4\% (114) of them were married. $98.4 \%$ of them were Sinhalese and Buddhist. Table 1 shows that the demographic characteristics of the working categories of the working staff.

Table 1: Socio- demographic characteristics of the respondents

\begin{tabular}{|l|l|c|}
\hline Socio- demographic characteristics & $\mathrm{N}(\%)$ \\
\hline Sex & Male & $117(97.5 \%)$ \\
\hline & Female & $3(2.5 \%)$ \\
\hline Marital status & & $114(95 \%)$ \\
\hline & Married & $6(5 \%)$ \\
\hline Buddhist & Unmarried & $120(100 \%)$ \\
\hline Race & & $120(100 \%)$ \\
\hline Occupation & Sinhalese & $71(58.2 \%)$ \\
\hline & & $34(27.9 \%)$ \\
\hline & Driver & $8(6.6 \%)$ \\
\hline & Conductor & $7(5.7 \%)$ \\
\hline & Mechanic & \\
\hline
\end{tabular}

\section{Health Status of the respondents According to Ashtavida pariksha}

Majority of the respondents were having normal pulse rate presenting (117.6) $98 \%$ and $2 \%$ of them were having tachycardia. They were taking allopathic medicine for that condition and also they were bus drivers. $97.5 \%$ of the respondents were having normal frequency of urination. Most of the respondents were having normal urine presenting 110 (91.7\%). 82.8\% (101) of the respondents were had normal mala pravrthi. $19 \%$ of them were suffered from constipation due to intake of less water. $87.7 \%$ (107) having normal sounds of the heart. $13 \%$ (10.7) were having abnormal sounds of the heart.100\% (120) were had normal vision. When investigation of the tongue $85.2 \%$ (104) of the respondents were having nirama condition and $14.8 \%$ (16) were had sama condition. 
According to their akruthi pariksha, 98.4\% (118) of them were had normal akruthi. $0.8 \%$ were had vikruthi deha which is congenital. Table 2 shows the result of Ashtavida pariksha of the respondents. Table 2 shows the Astavidha parikasha of the respondents.

Table 2; Astavidha parikasha of the respondents.

\begin{tabular}{|c|r|}
\hline Type of pariksha & $\mathrm{N}(\%)$ \\
\hline Nadi(Pulse) & $117(97.5 \%)$ \\
\hline Normal & $3(2.5 \%)$ \\
\hline Trachycardia & 0 \\
\hline Bradicardia & $112(93.3 \%)$ \\
\hline Muthra (Urine) & $8(6.7 \%)$ \\
\hline Normal & $101(84.2 \%)$ \\
\hline Poly uria & $19(15.8 \%)$ \\
\hline Mala (Stoo) & $104(86.7 \%)$ \\
\hline Constipation & $16(13, .3 \%)$ \\
\hline Jihva(Tongue) & $120(100 \%)$ \\
\hline Normal & $110(91.7 \%)$ \\
\hline Coated & $10(8.3 \%)$ \\
\hline Druk (Eyes) & $107(89.2 \%)$ \\
\hline Normal & $13(10.8 \%)$ \\
\hline Sparsha (Touch) & $118(98.3 \%)$ \\
\hline Normal & \\
\hline Pain & \\
\hline Sabdha (Sound) & \\
\hline No Crepitation & \\
\hline Crepitation & \\
\hline Normal & \\
\hline Abnormal & \\
\hline & \\
\hline
\end{tabular}

In sparsha pareeksha 10 (8.3\%) were had sparsha asakyatha due to sandhi shulatha. Specially those who were with constipation all those suffer from joint pains. According to Akruthi pariksha, $118(98.4 \%)$ of the respondents were having normal akruthi in their body structure but $2(1.6 \%)$ of them had abnormalities.

Outcome of the vaykrutha pariksha (Investigations) of the respondents.

Table 3 shows the investigation outcome of the respondents. 
Table 3: Investigation outcome of the respondents

\begin{tabular}{|c|r|}
\hline Type of Investigation & $\mathrm{N}(\%)$ \\
\hline Random blood sugar & $104(86.7 \%)$ \\
\hline Normal & $16(13.7)$ \\
\hline High & $105(87.5)$ \\
\hline Blood pressure & $8(6.7 \%)$ \\
\hline Normal & $7(5.8 \%)$ \\
\hline High & $110(91.7 \%)$ \\
\hline Low & $20(8.3)$ \\
\hline Urine albumin trace & \\
\hline Normal & \\
\hline trace & \\
\hline
\end{tabular}

Majority of the respondents' random blood sugar were normal presenting 85.2\% (104). $86.1 \%$ (105) of the respondents were had normal blood pressure. According to the urine albumin test outcome, almost all the respondents were not trace in $91.7 \%$ (110) .respondents.

\section{Health status of the respondents}

Table 3 shows the investigation outcome of the respondents.

\begin{tabular}{|l|r|}
\hline Type of the diseases & N (\%) \\
\hline No NCD & $36(30 \%)$ \\
\hline Diabetic & $45(37.5 \%)$ \\
\hline Hyperlipidemia & $3(2.5 \%)$ \\
\hline Hypertension & $4(3.33 \%)$ \\
\hline Diabetic, Hypertension & $1(0.83)$ \\
\hline Diabetic, Cholesterol, Hypertension & $1(0.83)$ \\
\hline Sandhi roga (Joint pains) & $14(11.7 \%)$ \\
\hline Gastritis & $15(12.5 \%)$ \\
\hline Cattah & $1(0.83 \%)$ \\
\hline Total & $120(100 \%)$ \\
\hline
\end{tabular}

Considering the health status of the respondents nearly one fourth of the respondents were healthy not any victim of Non communicable diseases presenting 30\% (36). There was only who is suffered from diabetic, hyperlipidemia and Hypertension. But most of them were suffered from Diabetic mellitus which was $37.5 \%$ (45) of the sample. According to their Body mass index it has calculated the nutritional status of the respondents. Table 4 shows the Nutritional status of the respondents. 
Table 4: Nutritional Status of the respondents

\begin{tabular}{|l|l|}
\hline Nutritional status & $\mathrm{N}(\%)$ \\
\hline Low weight & $2(1.67)$ \\
\hline Normal weight & $64(53.33)$ \\
\hline Over weight & $54(45 \%)$ \\
\hline Total & $120(100 \%)$ \\
\hline
\end{tabular}

More than half of the respondents were normal weight which was $53.33 \%$ (64) but $45 \%$ of them were overweight.

Comparing the Relationship between nutritional status and the Non-communicable diseases of the respondents.

Table 5 shows that the relationship between nutritional status and the noncommunicable diseases of the respondents.

\begin{tabular}{|c|c|c|c|c|c|c|c|c|c|}
\hline \multirow{2}{*}{$\begin{array}{l}\text { Nutriti } \\
\text { onal } \\
\text { status }\end{array}$} & \multicolumn{9}{|c|}{ Non communicable Diseases } \\
\hline & $\begin{array}{c}\mathrm{No} \\
\mathrm{NC} \\
\mathrm{D}\end{array}$ & $\begin{array}{l}\text { Diabet } \\
\text { ic }\end{array}$ & $\begin{array}{c}\text { Hyperlipi } \\
\text { demia }\end{array}$ & $\begin{array}{c}\text { Hyperte } \\
\text { nsion }\end{array}$ & $\begin{array}{c}\text { Diabetic } \\
\text {, } \\
\text { Hyperte } \\
\text { nsion }\end{array}$ & $\begin{array}{c}\text { Diabetic } \\
\text {, } \\
\text { Cholest } \\
\text { erol, } \\
\text { Hyperte } \\
\text { nsion }\end{array}$ & $\begin{array}{c}\text { Sand } \\
\text { hi } \\
\text { roga }\end{array}$ & $\begin{array}{l}\text { Gastri } \\
\text { tis }\end{array}$ & Other \\
\hline $\begin{array}{l}\text { Low } \\
\text { weight }\end{array}$ & 0 & $\begin{array}{c}1(0.83 \\
\%)\end{array}$ & 0 & 0 & 0 & 0 & $\begin{array}{c}1 \\
(0.83 \\
\%)\end{array}$ & 0 & 0 \\
\hline $\begin{array}{l}\text { Norma } \\
1 \\
\text { weight }\end{array}$ & $\begin{array}{c}20 \\
(16.7 \\
)\end{array}$ & $\begin{array}{c}19 \\
(15.8 \\
\%)\end{array}$ & 0 & $3(2.5 \%)$ & $\begin{array}{c}1(0.83 \% \\
)\end{array}$ & 0 & $\begin{array}{c}9 \\
(7.5 \\
\%)\end{array}$ & $\begin{array}{c}11 \\
(9.16 \\
\%)\end{array}$ & $\begin{array}{l}1(0.8 \\
3 \%)\end{array}$ \\
\hline $\begin{array}{l}\text { Over } \\
\text { weight }\end{array}$ & $\begin{array}{c}16 \\
(13.3 \\
\%)\end{array}$ & $\begin{array}{c}25(20 . \\
8 \%)\end{array}$ & $3(2.5 \%)$ & $\begin{array}{c}1(0.83 \% \\
)\end{array}$ & 0 & $\begin{array}{c}1(0.83 \% \\
)\end{array}$ & $\begin{array}{c}4(3.3 \\
3 \%)\end{array}$ & $\begin{array}{c}4(3.33 \\
\%)\end{array}$ & 0 \\
\hline Total & $\begin{array}{c}36 \\
(30 \\
\%)\end{array}$ & $\begin{array}{c}45(37 . \\
5 \%)\end{array}$ & $3(2.5 \%)$ & $\begin{array}{c}4(3.33 \% \\
)\end{array}$ & $\begin{array}{c}1(0.83 \% \\
)\end{array}$ & $\begin{array}{c}1(0.83 \% \\
)\end{array}$ & $\begin{array}{c}14 \\
(11.7 \\
\%)\end{array}$ & $\begin{array}{c}15(12 . \\
5 \%)\end{array}$ & $\begin{array}{l}1(0.8 \\
3 \%)\end{array}$ \\
\hline
\end{tabular}

There was a significant differences among the nutritional status and Non- communicable diseases of the respondents' following the $\mathrm{X}^{2}(1, \mathrm{~N}=120)=0.422, \mathrm{p}=0.031$. It shows that there was a relationship between nutritional status and Non- communicable diseases of the workers at the Bus depot which is $\mathrm{p}$ value less than 0.05 .

\section{Discussion}


Present study proved that the more than half of the staffs were victims of the Noncommunicable diseases. Similar study done by the Wang at el, 2001 has showed the pattern of that risk of Coronary heart diseases morbidity and mortality for bus drivers (Wang, P. D., \& Lin, R. S.at el, 2001). Also study done by Winkleby et al, 1988 found out $42 \%$ of the Russian bus drivers had hypertension with positive relationship between hypertension and length of services (Winkleby, M. A. at el 1988). Present study showed that the $11.4 \%$ of the respondents were with shandhi roga (joint pains). Similar study also proved that that employment in the municipal transport system is the risk factor responsible for the development of serious diseases such as musculoskeletal disorders and neoplasms (Suzanna szubert at el 2005). In the present study more than half of the respondents were drivers and also $45 \%$ of the respondents were overweight. $75 \%$ of them were taking their meals from out door. This combination has proved by showing that Smoking and systolic blood pressure rates were similar between the drivers and the control group, however drivers were more obese (Hedberg, Jacobsson, at el, 1993). Obesity as a CHD risk factor has been implicated along with driver's irregular eating habits, low levels of physical activity at work and at leisure, smoking and even poor social networking (Hedberg, G. E at el, 1993).

\section{Challenges}

Workers who were working as bus drivers, conductors and mechanics were faced more health challenges in their working setup. Mainly meals of their today life have to take from outdoor due to the long distance travel and the roaster system.

\section{References}

1) Food and Agricultural Organization. Nutrition and Development: A Global Assessment. International Conference on Nutrition, Rome; 1992. p. 23-5

2) Hedberg, G. E., Jacobsson, K. A., Janlert, U., \& Langendoen, S. (1993). Risk indicators of ischemic heart disease among male professional drivers in Sweden. Scandinavian Journal of Work, Environment and Health, 19, 326-333.

3) M A Winkleby, 1988 jun, Excess risk of sickness and diseases in bus drivers: A review and synthesis of epidemiological studies.

4) M. D. Hossain and L. Ahmed, "Quality of working life and nutritional status in a sample of industrial workers," Bangladesh Journal of Nutrition, vol. 18-19, no. 20052006, pp. 43-51, 2015.

5) Medhi, G.K., Hazarika, N.C., Shah, B. and Mahanta, J. (2006). Health problems and nutritional status of tea garden population of Assam. Journal of Medical Science, 60(12): 496-505.

6) NCD. Alliance report 2012-2013. Putting non-communicable diseases on the globalagenda

7) P. A. Schulte, G. R. Wagner, A. Ostry et al., "Work, obesity, and occupational safety and health," American Journal of Public Health, vol. 97, no. 3, pp. 428-436, 2007.

8) Ronnenbeg, A.G., Goldman, M.B., Aitken, I.W., Xu, X. (2000). Anemia and deficiencies of foliate and vitamin B-6 are common and vary with season in Chinese women of child bearing age. Journal of Nutrition, 130: 2703-2710 
9) Wang, P. D., \& Lin, R. S. (2001). Coronary heart disease risk factors in urban bus drivers. Public Health, 115, 261-264

10) Winkleby, M. A., Ragland, D. R., Fisher, J. M., \& Syme, S. L. (1988a). Excess risk of sickness and disease in bus drivers: A review and synthesis of epidemiological studies. International Journal of Epidemiology, 17, 255-261

11)Zuzanna Szubert, Wojciech Sobala, Health reasons for work disability among municipal transport drivers , National Library of Medicine, 2005,56(4) 285-93

12) Wikepedia

13) World Health Organisation. Nutrition for Health and Development. Geneva: World Health Organisation; 2000. p. 34-59.

14) World Health Organisation. Nutrition for Health and Development. Geneva: World Health Organisation; 2000. p. 34-59. 